\title{
Müzik Öğretmeni ve Müzik Öğretmeni Adaylarına Yönelik Yansıtıcı Düşünme Eğilimi Ölçeği Geçerlik Güvenirlik Çalışması
}

\author{
Reflective Thinking Tendency Scale for Music Teachers and \\ Preservice Music Teachers: A Validity and Reliability Study
}

\author{
Sermin BILEN $N^{l}$
}

${ }^{I}$ Dr. Ö̆gr. Üyesi, Güzel Sanatlar Eğitimi Bölümü, Buca Eğitim Fakültesi, Dokuz Eylül Üniversitesi, İzmir/Türkiye, sermin.bilen@deu.edu.tr, (https://orcid.org/0000-0002-9287-4615)

Geliş Tarihi:23/03/2021

Kabul Tarihi:23/05/2021

\section{ÖZ}

$\mathrm{Bu}$ araştırmanın amacı, müzik öğretmeni ve müzik öğretmeni adaylarına yönelik geçerli ve güvenilir bir yansıtıcı düşünme eğilimi ölçeği geliştirmektir. Araştırmanın yöntemini tarama modeli oluşturmuştur. Araştırma grubunu, 2020-2021 öğretim yılında araştırmaya gönüllü olarak katılan, müzik öğretmeni ve müzik öğretmeni adaylarından oluşan toplam 634 katılımcı oluşturmuştur. Verilerin çözümlenmesinde, açımlayıcı ve doğrulayıcı faktör analizleri kullanılmıştır. Açımlayıcı faktör analizi için eldeki örneklemin yeterliği Kaiser-Meyer-Olkin örneklem yeterliği değeri ile incelenmiş, $\mathrm{KMO}=.885, \mathrm{sd}=120$ bulunmuştur. $\mathrm{Bu}$ sonuçlar açımlayıcı faktör analizi için örneklemin yeterli olduğunu göstermektedir. Değişkenler arası korelasyonun yeterliği için yapılan Bartlett küresellik testinde $\mathrm{x}^{2}=3444.481$ ve $\mathrm{sd}=120$ olarak bulunmuştur. Açımlayıcı faktör analizi sonuçlarına göre dört alt faktörde toplanan ve 16 maddeden oluşan ölçeğin faktörleri toplam varyansın \%71,35'ini açıklamaktadır. Ölçeğin faktör yük değerleri .536-.878 arasında değişmektedir. 1. faktör "ses eğitimine ilişkin problem çözme", 2. faktör "yaratıcılığa ilişkin planlama ve değerlendirme" 3. faktör "deneyimleri yansıtma ve değerlendirme" ve 4. faktör ise "öğrenmeyi kolaylaştırıcı strateji geliştirme” olarak adlandırılmıştır. Ölçeğin tümüne ilişkin Cronbach-Alpha iç tutarlılık katsayısı 0,91'dir. Faktörlerin Cronbach-Alpha katsayıları 1. faktör için 0.89, 2. faktör için 0.886, 3. faktör için $0.824,4$. faktör için ise 0.863 olarak bulunmuştur. Elde edilen bu değerler, her bir faktörün yüksek iç geçerliğe sahip olduğunu göstermektedir. Dört faktörlü yapı doğrulayıcı faktör analizi ile sınanmıştır. Doğrulayıcı faktör analizi sonuçlarına göre; RMSEA $=0,058$ (\%90 güven aralığ $=0.044-$ $0.072), \mathrm{CFI}=.96, \mathrm{IFI}=.96, \mathrm{AGFI}=.89, \mathrm{GFI}=.93$ ve $\mathrm{RMR}=159.23, \mathrm{sd}=83$ 'dür. Ki-kare $/$ sd son yapılan modifikasyon ile 1.91 bulunmuştur. $\mathrm{Bu}$ sonuç modelin mükemmel bir uyum içinde olduğunu belirtmektedir.

Anahtar Kelimeler: Müzik öğretmeni, müzik öğretmeni adayı, yansıtıcı düşünme, geçerlik ve güvenirlik.

\begin{abstract}
The purpose of this research is to develop a valid and reliable reflective thinking tendency scale for music teachers and preservice music teachers. The method of the research was the survey model. The study group of this research is composed of two independent datasets with sample size of 634 suitable and volunteer participants. The data were analyzed by exploratory and confirmatory factor analyzes. For the exploratory factor analysis, the Kaiser-Meyer Olkin sample adequacy value has been found as $0.855, \mathrm{x}^{2}$ as 3444.481 in Bartlett Sphericity test, and degree of freedom as 120. According to results of exploratory factor analyze, it was seen that the scale has four sub-factors with an eigenvalue greater than 1 , and these four sub-factors explained $71.35 \%$ of the total variance. The factor load values of the scale vary between $.536-.878$. Following the analysis of the items related to the factors, the first factor was named as "problem solving in voice education", the second factor was named as "planning and evaluating in creativity", the
\end{abstract}


third factor was named as "reflecting and evaluating the experiences" and the fourth factor was named as "developing a strategy for facilitating learning". The Cronbach-Alpha internal consistency coefficient for the overall scale was calculated as 0.91 . The Cronbach-Alpha coefficients of the factors were 0,89 for the 1 st factor, 0.886 for the 2 nd factor, 0.824 for the 3 rd factor, and 0,863 for the 4 th factor. These values demonstrate that each factor has a high degree of internal validity. The four-factor structure was tested by confirmatory factor analysis. According to the results of the confirmatory factor analysis, the values were obtained as RMSEA $=0.058(90 \%$ confidence interval $=0,044-0,072), \mathrm{CFI}=.96, \mathrm{IFI}=.96, \mathrm{AGFI}=.89$, $\mathrm{GFI}=.93$, and $\mathrm{RMR}=.030$. Chi-square $=159.23, \mathrm{df}=83$. The fact that the chi-square $/ \mathrm{df}$ is 1.91 following the last modification indicates that the model is in perfect harmony.

Keywords: Music teacher, music teacher candidate, reflective thinking. validity and relibility.

\section{GİRIS}

İlk kez Dewey ile eğitim dünyasına giren yansıtıcı düşünme; problem çözme, eleştirel düşünme, yaratıcı düşünme ve üst bilişsel düşünme ile iç içe geçen, kapsamlı bir üst düzey düşünme becerisidir. Eğitimin tüm alanlarındaki öğrenme-öğretme süreçlerinin niteliğine vurgu yapan yansitıcı düşünme, öğretmenlerde öğrenciliklerinden başlayarak geliştirilmiş olması beklenen ve gelişmeye devam etmesi gereken bir beceridir. Öğretmenlerin yansitıcı düşünme becerisinin öğrenciliklerinden itibaren geliştirilmeye başlanması, öğretmen adaylarının ileriki mesleki yaşamlarında yansıtıcı öğretmen olmalarının temelini atar. Jay ve Johnson (2002) öğretmen yetiştirmede yansitıcı düşünmenin, hizmet öncesinde öğretmenlere "öğretmen gibi düşünmeyi" çok sayıda değişik yollarla öğretip, öğretmenlerin bunları yansıtmalarını sağlaması açısından önemli olduğunu belirtmektedirler (aktaran Köksal ve Demirel, 2008, s.190).

Elliott (1992) müzik öğretmeni eğitimcilerinin, müzik eğitiminde yansıtıcı uygulayıcılar yetiştirmek için, prosedürel bilgileri durumsal bilgilerle birleştirebilecek biçimde eğitmeleri gerektiğini açıklamaktadır. "Prosedür bilgisi”" kavramını; "Uzmanlık, kişinin yaptığı şey hakkında söylediklerinde yatmaz; uzmanlık ölçüsü, uygulayıcının yaptığını ne kadar iyi yaptığıdır." olarak açıklayan Elliott, öğretmenlerin sorunlarını saptayıp çerçeveleyebilmeleri ve daha sonra bu sorunları uygulamada çözebilmelerinin gerekliliğini vurgulamaktadır (aktaran Hourigan, 2006, s.34). Kuşkusuz Elliot'un yansıtıcı müzik öğretmeni yetiştirmekle ilgili bu görüşleri eğitimin tüm alanları için de geçerlidir.

Demirel (2007, s.233) yansıtıcı düşünmenin eğitime yansıtılabilmesi için, temel düşünme becerileriyle desteklenen bir ortamın gerekliliğini ifade etmektedir. Eğitim ortamının temel düşünme becerileriyle desteklenmesi, öğretmenin kendisini ve eğitim sürecini sorgulaması ile başlar. Dewey (1910, s.205),

- Öğrencilerin hangi deneyimlere sahip oldukları ve işlerine yarar neler öğrendikleri,

- Eldeki ekipman ve ekonomiyle konuların nasıl sunulacağı,

- Öğrencilerin ilgilerinin hangi objelere çekileceği,

- Nelerin kıyaslanıp, hangi benzerliklerin kurulacağı,

- Hangi tartışmaların sonuca vardığı sorularını kendisine soran ve bu soruları sistematik biçimde göz önünde bulunduran hiçbir öğretmenin başarısız olamayacağını belirtmektedir.

Dewey'in de vurguladığı gibi öğretmeni başarıya götürecek yol, kendisini öğrenmeöğretme süreci ile ilgili sürekli sorgulaması, bir diğer ifadeyle kendisine eleştirel bakmasından geçmektedir. Böylece eleştirel düşünme, yansıtıcı düşünmenin eğitime yansıttılabilmesi için gerekli olan temel düşünme becerilerinin ilk basamağını oluşturur.

Eleştirel düşünmeyi Paul (1991), sonuçlara ulaşmada gözlem ve bilgiyi kullanmak, Beyer ise (1987) bilginin doğruluk ve kesinliğinin değerlendirilmesi, inançların, argümanların ve bilgi iddialarının bir değeri olarak tanımlamaktadırlar (aktaran Aybek, 2007, s.45). Eleştirel düşünme 
becerisi; öğretmen ve öğrenci açısından öğrenme sürecinin etkisini ve niteliğini artıran çift yönlü bir etkileşim sunar. Öncelikle öğretmen; öğrenme-öğretme sürecinin etkili olup olmadığını ve kullandığı öğrenme stratejilerinin öğrencilerin öğrenmelerini kolaylaştırıp kolaylaştırmadığını sorgular, değerlendirir, geçmiş bilgileri ile yeni edindiği bilgileri harmanlayarak yeni düzenlemeler yapar. Yeni düzenlemeler bir yandan öğrencilerin öğrenmeyi öğrenmelerini sağlarken diğer yandan da kendi öğrenmeleri ile ilgili karşılaştıkları problemleri çözme becerilerini geliştirir. Eleştirel düşünme, öğrencilerin öğrenmeyle ilgili sınıf içi yaşadıkları problemleri çözmelerine yardımcı olmasının yanı sıra günlük yaşam içinde karşılaştıkları problemleri çözmelerine de destek olur.

Şahin, (2004, s.164-165) problem çözme becerisinin geliştirilmesinin;

- Öğrencileri bilgi alıcı olmaktan çıkarıp aktifleştirmek, kendi kendine öğrenen ve problem çözen bireylere dönüştürerek eğitim programlarının vurgusunu öğretmekten öğrenmeye kaydırmak,

- Bilgilerin ezberletilmesinden çok öğrencileri, çözülecek problemlerle karşı karşıya getirerek yeni bilgi, beceri kazanmalarını sağlamak,

- Öğrencilere problem çözmeyi kolaylaştıracak ortamlar hazırlamak gibi amaçları içerdiğini belirtmektedir.

Problem çözme becerisinin gelişmesi etkili bir öğretmen-öğrenci ilişkisi gerektirir. $\mathrm{Bu}$ etkili iletişim, öğrencide merak uyandırıp, onların araştırmaya yönlendirildiği ve bilgiyi keşfetmelerine rehberlik edildiği bir öğrenme ortamı oluşturur. Dewey'den itibaren öğrenmeöğretme sürecinin, öğrencileri düşündürerek onların bilgileri keşfedecekleri yaşantılar sağlanmasının gerekliliği eğitim kuramcılarının ortak görüşünü oluşturmuştur. Keşfederek öğrenme; çocukların bilgileri ezberlemeden, kalıcı öğrenmelerini sağlamanın yanı sıra yeteneklerini fark edip, geliştirme firsatları da oluşturur. "Piaget'ye göre yaratıcı, buluşçu, keşifçi insanlar denetleyici bir kafaya sahip olan ve kendilerine sunulan her şeyi olduğu gibi kabul etmeyen insanlardır" (Sungur, 1992, s.41). Piaget'nin vurguladığı bu özellikler, özgür bir öğrenme ortamında keşfederek öğrenme sayesinde gelişir.

Keşfederek öğrenme, Froebel, Dewey ve Montessori'nin eğitim felsefeleri ile temel bulmuş, Piaget ve Bruner'in gelişimsel teorileri ile ivme kazanmıştır. Çocukların sadece öğretmenin talimatlarını izleneceği bir yaklaşıma karşı çıkan bu eğitim kuramcıları; çocukların kendi öğrenme hızlarında ilerleyebilecekleri ve kendi tercih ettikleri etkinlikleri seçebilecekleri özgürlüklerinin olmasının gerekliliğine dikkat çekmektedirler (Otacıoğlu, 2008, s.72). Bu bakış açısı, öğrencinin merkeze alındığı, öğretmenin rehberlik rolünü üstlendiği aktif öğrenmenin temelini oluşturmuştur.

Açıkgöz (2008, s.39) aktif öğrenmede öğrencinin, geleneksel öğretimde olduğu gibi kendisine aktarılanları alan ve sonra onları tekrarlayan "boş bir kap" ya da "edilgin alıcı" olmadığını vurgulamaktadır. Aktif öğrenmede öğrenen, öğretilenleri aynen alma yerine, onları kendine özgü stratejilerle işleyip yeniden üretir. Bu öğrenme sürecinde, birbirleriyle etkileşimde bulunan, sorunlarını ve bilgilerini birbirleriyle paylaşan öğrenci; öğrenmeyi gerçekleştirmek için araştırır, düşünür, keşfeder. Aktif öğrenen öğrencilerin öz düzenlemeli, eleştirel ve yaratıcı düşüncelerini sergilemeleri beklenir.

Aktif öğrenmenin işlevlerinin gerçekleştirilebilmesinin en önemli ögesi öğretmendir. Dewey'in ifadesiyle (1910, s.220) öğretmek bir sanattır ve öğretmen de bir sanatçıdır. Dewey'in "sanatçı" olarak nitelendirdiği ögretmeni sıradan bir bilgi aktarıcısı olmaktan kurtaran ve bir sanatçı gibi öğrenme-öğretme sürecini sergilemesini sağlayan etmen, öğretmenin eleştirel düşünme ve problem çözme becerilerinin gelişimiyle temel bulan üst biliş ve yaratıcı düşünme becerisidir. Flavell'e (1976) göre üst biliş, kişinin kendi bilişsel süreçlerinin ya da herhangi bir konuda sahip olduğu bilginin farkında olmasıdır. Üst biliş; planlama, izleme ve değerlendirme gibi becerileri içerir (aktaran Köstekçi, 2016, s.52). Üst biliş becerisi gelişmiş öğretmen; 
öğrencilerinin öğrenme sitillerine ve öğrenme hılarına uygun, onların aktif katılımlarını sağlayacak öğrenme-öğretme süreçleri planlar. Uyguladığ 1 öğrenme stratejilerinin öğrenmeyi ve geliştirmeyi planladığı becerilerin gelişimini kolaylaştırıp kolaylaştırmadığını değerlendiren öğretmen, gerektiğinde öğrenme stratejilerini değiştirir ve geliştirir. Böylece öğretmenin üst biliş beceri düzeyi, onu yaratıcı düşünmeye yönlendirir. Sungur'un da (1992, s.41) belirttiği gibi eğitimin amacı, kendinden önceki kuşakların yaptıklarını yineleyen değil, yeni şeyler üretebilme yeteneği geliştirilmiş bireyler yetiştirmektir. Günay'ın (2011, s.87) tanımıyla da “eğitim; bireyin dış çevreden edindikleri ile kendi içsel dinamiklerinin bileşke davranışları biçiminde oluşan bilgi ve beceri birikimleriyle, karşılaştığı sorunları çözücü, çevreye uyum sağlatıcı, yaratıcı, üretici ve özgürleştirici etkileşimler bütünüdür". Günay’ın tanımındaki etkileşimler bütünü; problem çözmenin yanı sıra yaratıcılığı ön plana çıkaran bir öğrenme ortamındaki yaşanması gerekenlerdir.

Torrance'a göre (1974) yaratıcılık, "sorunlara; bozukluklara, bilgi eksikliğine, kayıp ögelere, uyumsuzluğa karşı duyarlı olma; güçlüğü tanımlama, çözüm arama, tahminlerde bulunma ya da eksikliklere ilişkin denenceler geliştirme, bu denenceleri değiştirme ya da yeniden sinama, daha sonra da sonucu ortaya koymaktır" (aktaran Sungur, 1992, s.20). Torrance'ın yaratıcılık tanımı, yansıtıcı düşünmenin odak noktaları olan eleştirel düşünme, problem çözme ve üst biliş becerilerini işaret etmektedir.

Tüm duygusal ve zihinsel etkinliklerde, her türlü çalışma ve uğraşın içinde yer alan yaratıcılık insan yaşamının ve gelişiminin temelini oluşturur. İçinde merak, imgelem, buluş, özgünlük gibi ögeleri içeren yaratıcılığın gelişimi, sorunlara yeni çözüm yolları bulma yetisini de geliştirir (San, 1977, s.12-13). Yaratıcılık, eğitimin tüm alanlarını kapsadığı gibi müzik eğitiminin de ana konularından birini oluşturur ve müzik öğretim programlarının temel öğrenme alanlarının içinde yer alır.

Müzik dersi öğretim programlarının genel amaçları arasında, müzik yoluyla;

- Duygu, düşünce ve deneyimleri ifade etme,

- Estetik yönü geliştirme,

- Kişilik gelişimine katkı sağlama,

- Zihinsel becerilerin gelişimine katkı sağlama,

- Müziksel alg1 ve bilgileri geliştirme,

- Ulusal ve evrensel kültür birikimi sağlama yer almaktadır.

Müzik dersi öğretim programları, bu amaçların gerçekleştirilmesine kaynaklık edecek; “dinleme-söyleme, müziksel alg1 ve bilgilenme, müziksel yaratıcılık, müzik kültürü olmak üzere dört temel öğrenme alanından oluşmaktadır (MEB, 2018). Bu öğrenme alanlarının işlevlerinin gerçekleştirilmesi, öğretmenlerin müzik bilgi ve beceri donanımlarına bağlıdır. Günay'ın da (2011, s.251) vurguladığ1 gibi müzik eğitimcilerinin mesleki yaşamlarında gerçekleştirmeleri beklenen davranışları sergileyebilmeleri için zengin bilgi ve beceri donanımıyla yetiştirilmeleri gerekir. Ancak böylece müzik eğitimcilerine gereken mesleki davranış özgürlüğü, problem çözme yetkinliği, yaratıcılığını kullanması aracılığıyla eğitim sanatından zevk duyması ve mesleki olarak kendisini gerçekleştirebilmesi sağlanabilir.

Müzik bilgi ve beceri birikimi mesleki donanımın çok önemli bir parçasıdır. Ancak, öğrenme-öğretme sürecinin etkililiği müzik eğitimcilerinin yansıtıcı düşünme becerilerinin gelişmesiyle olanaklıdır. Yansıtıcı düşünme becerisi, tüm eğitimciler için önemli olmakla birlikte müzik eğitimcileri açısından daha da önem arz etmektedir. Bunun nedeni; soyut bir sanat dalı olan müziğin duyumsanması, algılanması ve anlamlandırılmasının; sesin, çalgının etkili kullanımına, müzik okur-yazarlığına, müzikal ifade gücünün ve müziksel yaratıcılığın gelişimine yansıtılmasının oldukça komplike davranışlar bütünü olmasıdır. Bu davranışlar 
bütünü, aşılması gereken birçok kritik nokta ve çözülmesi gereken birçok problem içerir. Problemlerin çözülerek kritik noktaların aşılması, öğrencilerin müziksel potansiyellerinin gelişiminin temelini oluşturur, böylece müzik öğretmeni ile öğrencinin karşılıklı etkileşimi sıradanlıktan çıkar, adeta bir sanata dönüşür. Bu dönüşüm; öğrencilerin yaşamını müzikle zenginleştirmekle kalmaz, aynı zamanda onların dünyayı farklı bir pencereden keşfetmelerinin, günlük yaşam içinde karşılaştıkları problemlerin çözümünde çok boyutlu bir düşünme becerisi geliştirmelerinin ve estetik bir yaşam biçimini benimsemelerinin yolunu açar. $\mathrm{Bu}$ süreci sıradanlıktan çıkaran etken, müzik öğretmeninin yansıtıcı düşünme becerisidir.

Yansıtıcı düşünme becerisi gelişmiş bir müzik öğretmeni dışarıdan kendisine bir mercekle bakarak öncelikle planladığ bakıma kendisine karşı eleştirel bir bakış açısı geliştiren öğretmen; dinleme-söyleme, müziksel alg1 ve bilgilenme, müziksel yaratıcılık, müzik kültürü öğrenme alanlarıyla ilgili planladığ etkinlikleri etkili bir öğrenme-öğretme sürecine dönüştürmenin ilk adımını atar ve sorguladığ etkinlikleri iyileștirmenin yollarını arar. Müzik öğretmeni, öğrenciliğinden itibaren biriktirdiğgi bilgi ve beceriler ile yaratıcı potansiyelini kullanarak öğrenme-öğretme sürecini öğrencilerinin müziksel potansiyellerini en üst düzeye çıkaracak biçimde planlar ve uygular. Böylece yansıtıcı düşünmenin bir bileşkesi olarak kabul gören eleştirel düşünme, problem çözme, üst bilişsel düşünme ve yaratıcı düşünme becerileri ile sıkı bir bağ oluşturur.

Öğretmen ve öğrencilere karşılıklı yansıtıcı öğrenme-öğretme etkileşimi sunan yansıtıcı düşünme becerisi gelişimi ömür boyu öğrenmeye motive olmanın da yolunu açar. Bu nedenle oldukça önemsenen yansıtıcı düşünme birçok araştırmanın konusu olmuştur. Bu araştırmaların başında yansıtıcı düşünme becerisine yönelik ölçek geliştirme çalışmaları yer almaktadır. Türkiye'deki ilk yansıtıcı düşünme ölçeği çalışmalarından olan Semerci'nin (2007) ve Güney'in (2008) geliştirdikleri ölçekler öğretmen ve öğretmen adaylarına yönelik olup eğitimin tüm alanlarına uygulanabilir özelliktedir. Alp'in (2007) ve Dolapçıŏlu'nun (2007) yansitıcı düşünme ölçek çalışmaları sınıf öğretmenleri için düşünülmüştür. Filiz'in (2008) geliştirdiği ölçek ise, yabancı dil öğretmenlerinin yansıtıcı öğretime ilişkin yaklaşımlarını belirlemeye yöneliktir. Kızılkaya ve Aşkar'ın (2009) geliştirdiği problem çözmeye yönelik yansıtıcı düşünme becerisi ölçeği ile Yıldırım'ın (2012) geliştirdiği yansıtıcı düşünme ölçeği orta öğretim öğrencilerine uygulanabilir özelliktedir. Ayrıca, Çiğdem ve Kurt ile (2012) Başol ve Gencel'in (2013) Türkçe'ye uyarladıkları yansıtıcı düşünme becerisi ölçeği çalışmaları bulunmaktadır. Bu ölçekler, aralarında lisansüstü tezlerin de yer aldığı çeşitli alanlardaki birçok yansıtıcı düşünme araştırmasına kaynaklık etmiştir (Aydın ve Çelik, 2013; Duban ve Yelken, 2010; Durdukoca ve Demir, 2012; Eğmir ve Çengelci, 2020; Köstekçi, 2016; Saygıll ve Tehneldere, 2014; Sevgi ve Zihar, 2020; Şahin, 2011; Tümkaya ve Hurioğlu, 2013; Yumuşak, 2015). Burada bir kısmına yer verilen bu araştırmaların yanı sıra yayınlanmış daha birçok araştırmaya da ulaşmak mümkündür.

$\mathrm{Bu}$ araştırmaların arasında, müzik eğitiminde yansıtıcı düşünmeyle ilgili araştırmaların sayısının oldukça az olduğu dikkat çekmektedir. Bu araştırmalardan biri Okan'ın (2010), yansıtıcı düşünme etkinliklerinin piyano öğrenme sürecindeki akademik başarıya etkisini incelediği araştırmasıdır. Bir diğer araştırmada ise Erol ve diğ. (2019) sınıf ve okul öncesi öğretmenleri ile içlerinde müzik öğretmenlerinin de yer aldığ 1 çeşitli alan öğretmenlerinin yansıtıcı düşünme eğilimleri ile yaratıcı düşünme düzeyleri arasındaki ilişkiyi irdelemişlerdir.

Yurt dışı yayınlar, yansıtıcı müzik eğitiminin ülkemize göre daha çok önemsendiğini göstermektedir. Bu yayınlar arasında, uygulama alanı bulmuş ve araştırmalara kaynaklık etmiş olan "Arts Propel" (1992) adlı bir proje çalışması dikkat çekmektedir. Bu proje, Harvard Üniversitesi öncülüğünde, aralarında araştırmacı, psikolog, sanatçı, öğretmen ve öğrenciler ile test geliştirme servisinin yer aldığı Project Zero işbirliği ile geliştirilmiştir. Projenin amacı, sanat ve disiplinler arası birey ve gruplar için öğrenmeyi, düşünmeyi ve yaratıcılığı geliştirmektir. Proje, orta öğretim öğrencileri için müzik, görsel sanatlar ve yaratıcı yazma alanlarında öğretim ve değerlendirmeyi kapsayan programlar içermektedir (Winner, 1993). 
Hourigan (2006, s.33) müzik öğretmeni eğitmenlerinin öğrenci öğretmenlerin hizmet öncesinde yansıtıcı öğretmenler olarak yetiştirilmelerine yönelik, "Arts Propel" ve vaka yönteminin (case method) kullanıldığı, olumlu sonuçlara ulaşılmış olan araştırmalara dikkat çekmektedir (Conway, 1999; Lind, 2001; Richardson, 1997). Conkling'in (2003) banliyö bir okul bölgesinde oluşturulan koro müziği grupları ile gerçekleştirdiği kolektif vaka çalışmasında da hizmet öncesinde öğrenci müzik öğretmenlerini gerçek öğrencilerle karşılaştırarak öğretmeyi öğrenmelerinin sağlanması ve yansıtıcı düşüncelerinin açığa çıkartılması amaçlanmıştır. Phillips ve Stevens (2001) ise çalışmasında, lise koro çalışmalarında öğrencilerin yansıtıcı düşüncesini değerlendirerek öğrenci ve öğretmen uygulamalarını geliştirmeye odaklanmıştır. Gruenhagen (2017) Amerika'da ilkokul öğrencileriyle gerçekleştirdiği araştırmasında, müzik derslerinde yansıtıcı ve işbirliği uygulamaları aracılığıyla bağımsız, yaratıcı, müzikal düşünceleri geliştirecek stratejileri değerlendirerek öneriler getirmeyi amaçlamıştır.

Ülkemizde de müzik eğitiminde yansıtıcı düşünmeye yönelik oldukça sınırlı sayıdaki araştırmaların artırılması, müzik eğitiminin niteliğinin geliştirilmesi açısından oldukça önemlidir. Öğretmenin, eğitimin en önemli ögesi olduğu düşünüldüğünde müzik öğretmenleri ve müzik öğretmeni adaylarının yansıtıcı düşünme beceri düzeylerinin betimlenmesine yönelik ölçme araçlarına gereksinim vardır. Bu çalışmalar, birçok araştırmaya kaynaklık ederek bu alandaki boşluğun doldurulmasında önemli rol oynayacaktır.

$\mathrm{Bu}$ araştırmanın amacı müzik öğretmeni ve müzik öğretmeni adaylarına yönelik geçerli ve güvenilir bir yansıtıcı düşünme eğilimi ölçeği geliştirmektir. Araştırma Türkiye'de müzik öğretmeni ve müzik öğretmeni adaylarına yönelik ilk yansıtıcı düşünme eğilimi ölçeği olması açısından önemlidir. Ayrıca uluslararası veri tabanlarındaki araştırmalar arasında da "müzik öğretmeni ve müzik öğretmeni adaylarına yönelik yansıtıcı düşünme becerisi ölçeği" ile ilgili bir araştırmaya rastlanmamıştır.

Bu ölçeğin; müzik öğretmenleri ve müzik öğretmeni adaylarının yansıtıcı düşünme beceri düzeylerinin betimleneceği araştırmalara ve müzik öğretmeni yetiştirme programlarında yansıtıcı öğretmen yetiştirmeye yönelik düzenlemelere temel oluşturacağı düşünülmektedir. Ayrıca bu araştırmanın, nitelikli öğrenme-öğretme süreçleri planlama ve uygulama aşamalarında müzik öğretmenlerinde farkındalık oluşturacak ve kendilerini yansıtıcı öğretmen olma yönünde geliştirecek adımları atmalarına ön ayak olacağı umulmaktadır. Böylece; yansıtıcı müzik öğretmenleri aracılığıyla kendisine ve çevresine eleştirel bakabilen, sorgulayan, problem çözebilen, bağımsız hareket yetisi gelişmiş, kendisini müzikal olarak ifade edebilen, yaratıcı ve yaşamını müzikle zenginleştirebilen öğrencilerin yetiştirilmesi de olanaklı olacaktır.

\section{YÖNTEM}

$\mathrm{Bu}$ araştırmada nicel araştırmalar kapsamında ele alınmakta olan tarama yöntemi kullanılmıştır. "Bir grubun belirli özelliklerini belirlemek için verilerin toplanmasını amaçlayan çalışmalara tarama (survey) araştırması denir” (Büyüköztürk ve dĭğ., 2014, s.14). Bu araştırmada da müzik öğretmeni ve müzik öğretmenlerinin yansıtıcı düşünme eğilimi özelliklerini yansıtacak maddeleri içeren ölçek aracıllğıyla veriler toplanarak, ölçeğin geçerlik ve güvenirlik çalışmasına temel oluşturulmuştur.

\section{1. Ölçeğin Ön Deneme Formunun Geliştirilme Așamaları}

Çalışmanın ilk aşamasında yansıtıcı düşünme ile ilgili alanyazın taranmış, MEB (2018) müzik dersi öğretim programları ile önceden geliştirilmiş olan ölçekler ve maddeleri incelenmiştir. Bu incelemeler doğrultusunda yansıtıcı düşünme ile ilgili olan eleştirel düşünme, problem çözme, üst bilişsel düşünme ve yaratıcı düşünme ile müzik dersi öğretim programlarının dört temel alanını oluşturan dinleme-söyleme, müziksel algı ve bilgilenme, müziksel yaratıcılık, müzik kültürüne yönelik 47 madde oluşturulmuştur. Ölçek "hiç katılmıyorum", "katılmıyorum", 
"kısmen katılıyorum", "katılıyorum" ve "tamamen katılıyorum" olmak üzere beşli (5) likert tipinde düzenlenmiştir.

Hazırlanan ön deneme formu yedi müzik eğitimi uzmanının görüşüne sunulmuştur. Uzmanların görüşleri doğrultusunda 47 maddelik ölçek 45 maddeye indirilerek ölçek maddeleri yeniden düzenlenmiştir. Uzman görüşü sonucunda son halini alan ön deneme formu online form olarak düzenlenerek araştırma grubuna ulaştırılmıştır.

\subsection{Araştırma Grubu}

Araştırma grubu uygun örnekleme yöntemi ile belirlenmiştir. Uygun örneklemede, araştırmacılar katılımcıları kolay ulaşılabilir; araştırma için uygun ve gönüllü bireylerden seçmektedir (Gravetter ve Forzano, 2012; aktaran Başaran, 2017, s.489). Araştırmacı gereksinim duyduğu sayıya ulaşana kadar en ulaşılabilir olan yanıtlayıcılardan başlayarak örneklemi oluşturmaya başlar ya da en ulaşılabilir ve maksimum tasarruf sağlayacak bir durum, örnek üzerinde çalışır (Cohen ve Manion, 1989; Ravid, 1994; aktaran Büyüköztürk ve diğ., 2014, s.92).

Araştırma, farklı analizler için farklı veri setleri ile yapılmıştır. $\mathrm{Bu}$ nedenle farklı zamanlarda iki kere veri toplaması yapılmıştır. Ölçeği yanıtlamaya gönüllü olan toplam katılımcı sayısı 634'tür. Araştırmanın katılımcıları aşağıdaki özellikleri taşımaktadır:

- Eğitim fakülteleri müzik eğitimi anabilim dallarından mezun olanlar.

- Çeşitli müzik okullarından mezun, formasyon eğitimi almış olanlar.

- Eğitim fakültelerinin müzik eğitimi anabilim dallarının ikinci, üçüncü ve dördüncü sınıflarında öğrenci olanlar.

- Müzik öğretmenliği programı lisansüstü öğrencisi olanlar.

Ön deneme formu, açımlayıcı faktör analizi için Ocak 2021 tarihinde 362 katılımcıya uygulanmıştır. Açımlayıcı faktör analizi veri setine ilişkin betimleyici bilgiler Tablo 1'de verilmiștir.

Tablo 1. Açımlayıcı Faktör Analizi Veri Setine İlişkin Demografik Bilgiler

\begin{tabular}{lcrrrr}
\hline & & Frekans & Yüzde & $\begin{array}{r}\text { Geçerli } \\
\text { Yüzde }\end{array}$ & Toplam Yüzde \\
\hline Öğrenim & Mezun & 216 & 59,7 & 59,7 & 59,7 \\
Durumu & 2. sinıf & 43 & 11,9 & 11,9 & 71,5 \\
& 3. sinıf & 16 & 4,4 & 4,4 & 76,0 \\
& 4. snnıf & 81 & 22,4 & 22,4 & 98,3 \\
& Yüksek lisans & 4 & 1,1 & 1,1 & 99,4 \\
Fakülte & Doktora & 2 & 0,6 & 0,6 & 100,0 \\
& Eğitim & 310 & 85,6 & 85,9 & 85,9 \\
Deneyim & Diğer (formasyon almış) & 51 & 14,1 & 14,1 & 100,0 \\
& Yok & 114 & 31,5 & 31,5 & 31,5 \\
& $1-5$ yıl & 82 & 22,7 & 22,7 & 54,1 \\
& $6-10$ yıl & 50 & 13,8 & 13,8 & 68,0 \\
& $11-20$ yıl & 44 & 12,2 & 12,2 & 80,1 \\
Cinsiyet & 21 üstü & 72 & 19,9 & 19,9 & 100,0 \\
& Kadın & 128 & 35,4 & 35,4 & 35,4 \\
& Erkek & 234 & 64,6 & 64,6 & 100,0 \\
\hline
\end{tabular}

Açımlayıcı faktör analizi sonucunda 45 maddeden 16 maddeye inmiş olan ölçek, doğrulayıcı faktör analizi için oluşturulan 272 kişilik veri setine Şubat 2021 tarihinde uygulanmıştır. Doğrulayıcı faktör analizi veri setine ilişkin demografik bilgiler Tablo 2'de verilmiştir. 
Tablo 2. Doğrulayıcı Faktör Analizi Veri Setine İlişskin Demografik Bilgiler

\begin{tabular}{ccrrrr}
\hline & & Frekans & Yüzde & Geçerli Yüzde & $\begin{array}{r}\text { Toplam } \\
\text { Yüzde }\end{array}$ \\
\hline Öğrenim & Mezun & 173 & 63,6 & 63,6 & 63,6 \\
Durumu & 2. sınıf & 32 & 11,8 & 11,8 & 75,4 \\
& 3. sınıf & 23 & 8,5 & 8,5 & 83,8 \\
& 4. sinıf & 40 & 14,7 & 14,7 & 98,5 \\
& Yüksek lisans & 3 & 1,1 & 1,1 & 99,6 \\
Fakülte & Doktora & 1 & 0,4 & 0,4 & 100,0 \\
& Eğitim & 240 & 88,2 & 88,2 & 88,2 \\
Deneyim & Diğer (formasyon almış) & 32 & 11,8 & 11,8 & 100,0 \\
& Yok & 92 & 33,8 & 33,8 & 33,8 \\
& $1-5$ yıl & 31 & 11,4 & 11,4 & 45,2 \\
& 6-10 yıl & 30 & 11,0 & 11,0 & 56,3 \\
& $11-20$ yıl & 42 & 15,4 & 15,4 & 71,7 \\
Cinsiyet & 21 üstü & 77 & 28,3 & 28,3 & 100,0 \\
& Kadın & 108 & 39,7 & 39,7 & 39,7 \\
& Erkek & 164 & 60,3 & 60,3 & 100,0 \\
\hline & TOPLAM & 272 & 100 & 100 & \\
\hline
\end{tabular}

\subsection{Verilerin Toplanması ve Analizi}

Verilerin analizi aşamasında ilk olarak Ocak 2021 tarihinde 362 katılımcıya ulaşılmış ve elde edilen verilere açmlayıcı faktör analizi uygulanmıştır. Büyüköztürk (2007, s.123) faktör analizini birbirleri ile ilişki içerisinde olan birden çok değişkenin bir araya getirilerek kavramsal olarak daha az sayıda anlamlı yeni değişkenler elde etmeyi hedefleyen bir istatistik olarak tanımlamıştır. Ölçeğe açımlayıcı faktör analizinin uygulanması aşamasından önce ölçek maddelerinin madde-toplam ve maddeler arası korelasyonları incelenmiștir. İncelemeler sonucunda maddelerin arasındaki korelasyonun .20'den fazla olduğu görülmüş bu nedenle açımlayıcı faktör analizinde temel bileşenler analizi ve warimax rotasyon yerine maximum likelihood ve direct oblimin rotasyon kullanılmıştır. Şimşek (2007, s.100) temel bileşenler analizi ile varimax rotasyonun birbirleri ile daha az ilişkili maddelerde kullanılmasının uygun olduğunu belirtmiştir.

Açımlayıcı faktör analizi sonrasında, Şubat 2021 tarihinde 272 katılımcıdan oluşan bir diğer gruba ulaşılmış ve elde edilen verilere doğrulayıcı faktör analizi yapılmıştır. Doğrulayıcı faktör analizi (DFA) kuramsal bir temelden destek alarak pek çok değişkenden oluşturulan faktörlerin gerçek verilerle ne kadar uyum gösterdiğini değerlendiren bir uygulamadır (Büyüköztürk ve diğ., 2004). Doğrulayıcı faktör analizi Karl Jöreskog tarafından geliştirilmiş bir analizdir (Çelik ve Yılmaz, 2013).

\section{BULGULAR}

Analiz aşamasının ilk basamağında ölçeğin yapı geçerliğini incelemek için açımlayıcı faktör analizi uygulanmış, açımlayıcı faktör analizi sonucunda elde edilen yapının uyumu ise doğrulayıcı faktör analizi ile test edilmiştir. Araștırmada her iki analizi için ayrı veri setleri oluşturulmuştur. Açımlayıcı faktör analizi için eldeki örneklemin yeterliği Kaiser-Meyer-Olkin örneklem yeterliği değeri ile incelenmiş, $\mathrm{KMO}=.885, \mathrm{sd}=120$ bulunmuştur. $\mathrm{Bu}$ sonuçlar açımlayıcı faktör analizi için örneklemin yeterli olduğunu göstermektedir $(p<0,00)$. Değişkenler arası korelasyonun yeterliği için yapılan Bartlett küresellik testinde $\mathrm{x}^{2}=3444,481$ ve $\mathrm{sd}=120$ olarak bulunmuştur $(\mathrm{p}<0,01)$.

Analizin devamında, ölçeğin öz değeri 1'den büyük olmak üzere dört (4) alt faktöre sahip olabileceği ve bu 4 alt faktörün toplam varyansın \%71,35'ini açıkladığı görülmüştür Alt 
boyutların sahip olduğu öz değerler ve yamaç birikintisi grafiği (Şekil 1) incelendiğinde ölçeğin 4 alt faktörlü bir yapı olabileceği görülmektedir.

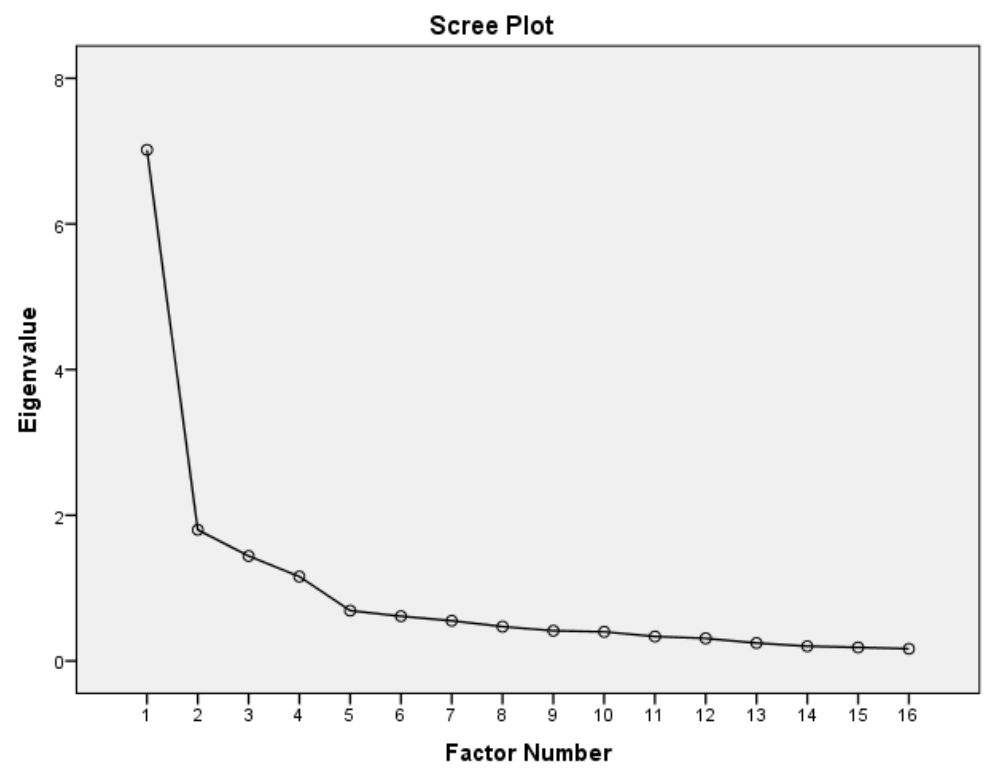

\section{Şekil 1. Yamaç Grafiği}

Analizde maddelerin yük değerlerinin kesim eşiği .50 olmasına karar verilmiştir. Tabachnick ve Fidell (2001), göre temel bir kural olarak her maddenin yük değerinin .32 ve üzerinde olması gerektiğini belirtir. Comrey ve Lee (1992), bir yük değerinin, .71 olması halinde "mükemmel", .63 olması halinde "çok iyi", .55 olması hâlinde "iyi", .45 olması halinde "vasat" ve .32 olması halinde "zayıf" olarak nitelendirilmesini önermişlerdir (aktaran, Tabachnick ve Fidell, 2001).

Ölçeğin faktör yük değerleri 1. faktörde .768-.878, 2. faktörde .738-.823, 3. faktörde .536$.790,4$. faktörde $.589-.852$ arasında değişmektedir. Faktörleri oluşturan maddeler incelendiğinde 1. Faktör "ses eğitimine ilişkin problem çözme", 2. faktör "yaratıcılığa ilişkin planlama ve değerlendirme" 3. faktör "deneyimleri yansıtma ve değerlendirme" ve 4. faktör ise "öğrenmeyi kolaylaştırıcı strateji geliştirme" olarak adlandırılmıştır. Tablo 3 'te ölçeğin faktörleri ve aldıkları yük değerleri verilmiştir.

Tablo 3. Ölçeğin Faktörleri ve Faktör Yükleri

\begin{tabular}{lllll}
\hline Maddeler & 1.Faktör & 2.Faktör & 3.Faktör & 4.Faktör \\
\hline 16 & 0,878 & & & \\
17 & 0,814 & & & \\
15 & 0,768 & 0,823 & & \\
41 & & 0,822 & & \\
38 & & 0,777 & & \\
39 & 0,738 & & \\
40 & & 0,790 & \\
2 & & 0,701 & \\
3 & & 0,650 & \\
1 & & 0,641 & $-0,852$ \\
4 & & 0,536 & $-0,744$ \\
7 & & & $-0,657$ \\
34 & & & $-0,589$ \\
33 & & & & \\
20 & & & & \\
10 & & & & \\
\hline
\end{tabular}


Analiz sonucunda 16 maddeden oluşan ölçeğin varyansın \%71,35'ini açıkladığ görülmüş̧ür. Dört faktörden oluşan ölçekte 1. faktör toplam varyansın 43,85'ini, 2. faktör 11,24'ünü, 3. faktör \%9,4 'ünü, 4. faktör \% $\%$,2' sini açıklamaktadır.

Faktörlerin iç geçerlikleri için Cronbach-Alpha katsayılarına bakılmıştır. Cronbach-Alpha katsayıları 1. faktör için $0,89,2$. faktör için $0,886,3$. faktör için $0,824,4$. faktör için ise 0,863 olarak bulunmuştur. $\mathrm{Bu}$ sonuçlar, alt boyutların yüksek iç geçerliğe sahip olduğunu göstermektedir. Ölçeğin tamamının Cronbach-Alpha katsayısı ise 0,91 olarak belirlenmiştir. Faktörler arası korelasyon değerleri Tablo 4'te verilmiştir.

Tablo 4. Faktörler Arası Korelasyon

\begin{tabular}{llll}
\hline $\mathrm{f} 1$ & $\mathrm{f} 2$ & $\mathrm{f} 3$ & $\mathrm{f} 4$ \\
\hline 1 & & & \\
$.471^{* *}$ & 1 & 1 & \\
$.449^{* *}$ & $.410^{* *}$ & $.554^{* *}$ & 1 \\
$.557^{* *}$ & $.515^{* *}$ & &
\end{tabular}

Elde edilen boyutların birbirleri arasındaki ilişki incelendiğinde tüm faktörlerin pozitif yönde ve orta kuvvette ilişki içinde oldukları görülmektedir.

Analizin devamında elde edilen 4 faktörlü yapı doğrulayıcı faktör analizi ile sınanmıştır. Analiz sonucuna ulaşılan sonuçlara göre $\mathrm{RMSEA}=0,077, \mathrm{CFI}=.93$, IFI $=.93$, AGFI $=.86$, GFI $=$ .90 ve $\mathrm{RMR}=.039$ olarak bulunmuştur. Modelin $\mathrm{x}^{2}$ değeri 219.07 serbestlik derecesi ise 84 'dir. $\mathrm{x}^{2} / \mathrm{sd}$ oranı $=2,60$. Alan yazında GFI ve AGFI değerlerinin 1 olmasının mükemmel uyum göstergesi olduğu belirtilmektedir (Çelik ve Yılmaz, 2013). Modelin uyum verileri incelendiğinde değerlerin kabul edilebilir olduğu görülmektedir. Tablo 5'te bir modelin sahip olmas1 gereken kabul edilebilir ve mükemmel uyum ölçütleri verilmiştir.

Tablo 5. Doğrulayıc1 Faktör Analizi Modelinin Uyum Değerlendirmesi

\begin{tabular}{lll}
\hline İndeks & Kabul edilebilir & Mükemmel uyum \\
\hline GFI & $<.90$ & $<.95$ \\
IFI & $<.90$ & $<.95$ \\
CFI & $<.90$ & $<.95$ \\
RMSEA & $>.08$ & $>.05$ \\
$\chi 2 / \mathrm{sd}$ & $2 \leq \mathrm{x} 2 / \mathrm{sd} \leq 3$ & $0 \leq \mathrm{x} 2 / \mathrm{sd} \leq 2$ \\
\hline
\end{tabular}

Tablo 5'deki veriler modelin sahip olduğu uyum değerlerinin kabul edilebilir sınırlar içinde olduğunu ortaya koymaktadır. Buna rağmen analiz sonucunda edinilen veri modifikasyon değerleri incelendiğinde daha iyi sonuçlar elde edilebileceği görülmektedir. Bu değerlere göre; madde 33 ile madde 34'ün hata değerleri arasında kovaryans tanımlaması yapılmasının ki-kare değişimini pozitif etkileyebileceği düşünülmüştür. Bu maddeler incelendiğinde; "Çalg1 öğretimi ile ilgili kendime özgü alternatif teknikler geliştiririm" ifadesinin yer aldığı madde 33 ile "Çalg1 çalışma çalışmalarında öğrencilerimin yaşadıkları problemleri çözecek stratejiler geliştiririm" ifadesinin yer aldığı madde 34'ün çalg1 eğitimine yönelik strateji geliştirmeyi temsil ettikleri görülmektedir. İki maddenin birbirleri ile ilişkili olmaları nedeniyle iki madde arasında hata kovaryansı tanımlaması yapılarak analiz tekrarlanmıştır. Yapılan ikinci analiz sonrasında modelin uyum değerlerinin geliştiği görülmektedir. $\mathrm{RMSEA}=0,058, \mathrm{CFI}=.96, \mathrm{IFI}=.96, \mathrm{AGFI}=.89, \mathrm{GFI}=$ .93 ve $\mathrm{RMR}=.030$ 'dur. Ki-kare $=159,23, \mathrm{sd}=83$. Ki-kare / sd'sinin son yap1lan modifikasyon ile 1.91 olması, modelin mükemmel uyum gösterdiğinin de kanıtı olarak değerlendirilebilir. Modelin diyagramı şekil 2'de verilmiştir. 


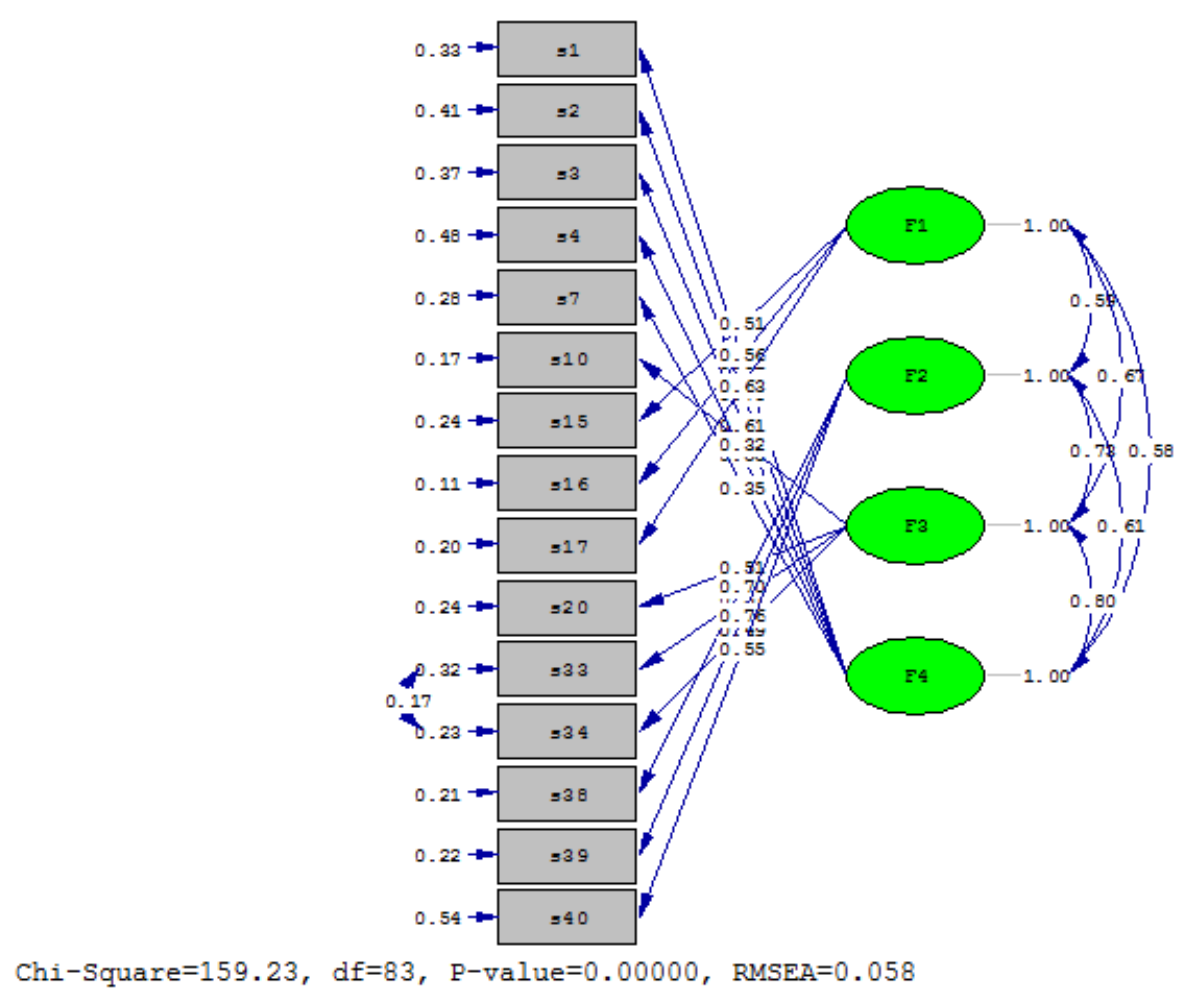

Şekil 2. Dört Faktörlü Yapıya İlişkin Doğrulayıcı Faktör Analizi Modeli

\section{SONUÇ TARTIŞMA VE ÖNERILER}

"Müzik öğretmeni ve müzik öğretmeni adaylarına yönelik yansıtıcı düşünme eğilimi ölçeği" geliştirmek amacıyla yapılmış olan bu araştırmanın başlıca sonuçları şöyledir:

- Toplam 16 maddeden oluşan dört faktörlü ölçekde, 1. faktör "ses eğitimine ilişkin problem çözme", 2. faktör "yaratıcılığa ilişkin planlama ve değerlendirme" 3. faktör "deneyimleri yansıtma ve değerlendirme" ve 4. faktör ise "öğrenmeyi kolaylaştırıcı strateji geliştirme" olarak adlandırılmıştır.

- Dört alt faktör toplam varyansın \%71,35'ini açıklamaktadır.

- Ölçeğin Cronbach-Alpha katsayıları 1. faktör için 0.89, 2. faktör için 0.886, 3. faktör için 0.824 , 4. faktör için ise 0.863 'dür. Ölçeğin tamamının Cronbach-Alpha katsayıs1 0,91olup, faktörler yüksek iç geçerliğe sahiptir.

- Doğrulayıcı faktör analizi sonuçlarına göre; RMSEA $=0.058, \mathrm{CFI}=.96, \mathrm{IFI}=.96$, AGFI $=.89$, GFI $=.93$ ve $\mathrm{RMR}=.030 . \mathrm{Ki}-\mathrm{kare}=159,23, \mathrm{sd}=83 . \mathrm{Ki}-\mathrm{kare} / \mathrm{sd}$ son yapilan modifikasyon ile 1.91'dir ve model mükemmel uyum göstermektedir.

$\mathrm{Bu}$ sonuçlar, bu ölçeğin geçerli ve güvenilir olduğunu ortaya koymaktadır. Alanyazında müzik öğretmeni ve müzik öğretmeni adaylarına yönelik yansıtıcı düşünme eğilimi ölçeği bulunmamakla birlikte, tüm alan öğretmeni ve öğretmen adaylarına yönelik az sayıda da olsa geliştirilmiş yansıtıcı düşünme ölçekleri bulunmaktadır. Bunlardan Semerci'nin (2007) öğretmen ve öğretmen adaylarına yönelik 35 maddelik yansıtıcı düşünme eğilimi ölçeği; sürekli ve amaçlı düşünme, açık fikirlilik, sorgulayıcı ve etkili öğretim, öğretim sorumluluğu ve bilimsellik, araştırmacı, öngörülü ve içten olma, mesleğe bakış adlı faktörlerden oluşmaktadır. Çiğdem ve Kurt'un (2012) Türkçeye uyarladıkları öğretmen adaylarına yönelik 16 maddelik yansıtı düşünme ölçekleri alışkanlık, anlama, yansıtma ve eleştirel yansıtma adlı faktörleri içerirken, Başol ve Gencel'in (2013) Türkçeye uyarladıkları öğretmen adaylarına yönelik 16 maddelik yansıtıcı 
düşünme düzeyi belirleme ölçeği ise alışkanlık, anlama, yansıtma, kritik yansıtma faktörlerinden oluşmaktadır.

Müzik öğretmeni ve müzik öğretmeni adaylarına yönelik yansıtıcı düşünme eğilimi ölçeği ile sözedilen ölçekler karşılaştırıldığında, bu ölçeğin maddelerinin ve faktörlerinin müzik alanına özgü olması en belirgin farkı oluşturmaktadır. Bunun yanı sıra ölçeklerdeki faktörler incelendiğinde, adları çok farklı gibi görünmekle birlikte faktörlerin öğretmen ve öğretmen adaylarının kendilerine ve öğrenme sürecine eleştirel bakması, problem çözmesi ve öğrenme sürecini etkili kılacak düzenlemeler yapması gibi ortak noktaları da taşıdığı görülmektedir.

Müzik eğitiminde öğrencilere müziğin duyumsatılması, onların müzikal ifade gücünün ve yaratıcı potansiyellerinin geliştirilmesi müziğin soyut bir sanat olması nedeniyle oldukça komplike bir yapı içerir. Bu komplike yapının öğrencinin gelişimini etkilemesi, müzik öğretmenlerinin öğrenciliklerinden itibaren müzik eğitiminin her bir öğrenme alanına özgü sanatsal ve yansıtıcı düşünme beceri donanımıyla yetiştirilmelerine bağlıdır. Müzik kendine özgüdür ve dolayısıyla sanatsal gelişimi destekleyecek kendine özgü ölçme araçları gerektirir. Yukarıda verilen araştırma sonuçlarının ortaya koyduğu gibi geçerli ve güvenilir olan bu ölçek, Türkiye'de bu alanda geliştirilmiş ilk ölçek olma özelliği ile önemli bir boşluğu dolduracaktır.

$\mathrm{Bu}$ doğrultuda, "müzik öğretmeni ve müzik öğretmeni adaylarına yönelik yansıtıcı düşünme eğilimi ölçeği” birçok müzik eğitimi araştırmasına temel oluşturabilir. Ölçek, betimsel araştırmaların yanı sıra müzik eğitiminde yansıtıcı düşünmeyle ilgili yarı deneysel araştırma modellerine de kaynaklık edebilir. Ayrıca müzik öğretmeni yetiştirme programlarının yansıtıcı müzik öğretmeni yetiştirmelerinin değerlendirilmesi ile ilgili başka ölçme araçlarının geliştirilmesine öncülük edebilir.

\section{KAYNAKÇA}

Açıkgöz, K. Ü. (2008). Aktif öğrenme. (8. Baskı). İzmir: Biliş Yayınları.

Alp, S. (2007). Illköğretim I. kademe öğretmenlerinin yansıtıcı düşünce üzerine bakış açıları. (Yayımlanmamış Yüksek Lisans Tezi). Çanakkale Onsekiz Mart Üniversitesi Sosyal Bilimler Enstitüsü. Çanakkale.

Aybek, B. (2007). Beceri temelli eleştirel düşünme öğretiminin öğretmen adaylarının eleştirel düşünme eğilimi ve düzeyine etkisi. Çanakkale Üniversitesi Sosyal Bilimler Enstitüsü Dergisi, 16(2), 43-60.

Aydın, M. ve Çelik, T. (2013). Sosyal bilgiler öğretmen adaylarının yansıtıcı düşünme becerilerinin bazı değişkenler açısından incelenmesi. Pamukkale Üniversitesi Eğitim Fakültesi Dergisi. 34(11), 169-181. doi:10.9779/PUJE611

Başaran, Y. K. (2017). Sosyal bilgilerde örnekleme kuram1. The Journal of Academic Social Science, 47, 480-495.

Başol, G. ve Gencel, İ. E. (2013). Yansıtıcı düşünme düzeyi belirleme ölçeği: Geçerlik ve güvenirlik çalışması. Kuram ve Uygulamada Eğitim Bilimleri, 13(2), 929-946.

Büyüköztürk, Ş. (2007). Sosyal bilimler için veri analizi el kitabı. Ankara: Pegem A Yayıncılık.

Büyüköztürk, Ş., Çakmak, E. K., Akgün, Ö. E., Karadeniz, Ş. ve F. Demirel. (2014). Bilimsel araştırma yöntemleri. Ankara: Pagem Akademi.

Büyüköztürk, Ş., Akgün, O. E., Özkahveci, O. ve Demirel, F. (2004). Güdülenme ve öğrenme stratejileri ölçeğinin Türkçe formunun geçerlik ve güvenirlik çalışması. Kuram ve Uygulamada Ë̆itim Bilimleri, 4(2), 207-239. 
Çelik, İ. ve Yılmaz, Y. (2013). Yapısal eşitlik modellemesi temel kavramlar uygulamalar programlama. Ankara: Anı Yayıncılık.

Congling, S. W. (2003). Uncovering preservice music teachers' reflective thinking: Making sense of learning to teach. Bulletin of the Council for Research in Music Education, 155, 11-23.

Çiğgdem, H. ve Kurt, A. A. (2012). Yansitıcı düşünme ölçeğinin Türkçeye uyarlanması. Uludăg Üniversitesi Ĕgitim Fakültesi Dergisi, 25(2). 475-493.

Demirel, Ö. (2007). Eğitimde program geliştirme. (10. Baskı). Ankara: Pegem A Yayıncılık.

Dewey, J. (1910). How we think. Newyork: Prometheus Books.

Dolapçığlu, S. D. (2007). Sinıf öğretmenlerinin yansitıcı düşünme düzeylerinin değerlendirilmesi. (Yayımlanlamamış Yüksek Lisans Tezi). Mustafa Kemal Üniversitesi Sosyal Bilimler Enstitüsü. Hatay.

Duban, N. ve Yelken, T. Y. (2010). Öğretmen adaylarının yansıtıcı düşünme eğilimleri ve yansıtıcı öğretmen özellikleriyle ilgili görüşleri. Çukurova Üniversitesi Sosyal Bilimler Enstitüsü Dergisi, 19(2), 343 - 360.

Durdukoca, Ş. F. ve Demir, M. (2012). İlköğretim öğretmenlerinin bazı değişkenlere göre yansitıcı düşünme düzeyleri ve düşüncelerdeki öğretmen niteliklerinin yansitıcı öğretmen niteliklerine uygunluğu. Mustafa Kemal Üniversitesi Sosyal Bilimler Enstitüsü Dergisi, (9)20, 357-374.

Eğmir, E. ve Çengelci, S. (2020). Öğretmenlerin 21. yüzyıl öğretim becerilerinin yansitıc1 düşünmeyi uygulama becerilerini yordama gücü. Journal of History School, 45, 10451077. doi: $\underline{10.29228 / \text { joh.32719 }}$

Erol, M., Erol, A., Çalışır, S. ve Bozan, M. (2019). Öğretmenlerin yansıtıcı düşünme eğilimleri ile yaratıcı düşünme düzeyleri arasındaki ilişkinin incelenmesi. Temel Eğitim Dergisi, 1(2), 20-29.

Filiz, Y. (2008). The attitudes of teachers of English as a foreign language towards reflective teaching. (Yayımlanmamış Yüksek Lisans Tezi). Uludağ Üniversitesi Sosyal Bilimler Enstitüsü. Bursa.

Gruenhagen, L. M. (2017). Developing musical creativity through reflective and collaborative practices. Music Educators Journal, 103(3), 40-45. doi:10.1177/0027432116685158

Günay, E. (2011). Müzik sosyolojisi sosyolojiden: Müzik kültürüne bir bakış. (2. Bask1). İstanbul: Müzik Bilimleri Dizisi.

Güney, K. (2008). Mikro-Yansıtıcı ögretim yönteminin öğretmen adaylarının sunu performansı ve yansitıcı düşünmesine etkisi. (Yayımlanmamış Doktora Tezi). Fırat Üniversitesi Sosyal Bilimler Enstitüsü. Elazığ.

Hourigan, R. (2006). The use of the case method to promote reflective thinking in music teacher education. Update: Applications of Research in Music Education, 24(2), 33-44. doi: $10.1177 / 87551233060240020104$

Kızılkaya, G. ve Aşkar, P. (2009). Problem çözmeye yönelik yansıtıcı düşünme becerisi ölçeğinin geliştirilmesi. Eğitim ve Bilim, 34(154), 82-92.

Köksal, N. ve Demirel Ö. (2008). Yansıtıcı düşünmenin öğretmen adaylarının öğretmenlik uygulamalarına yansımaları. Hacettepe Üniversitesi Eğitim Fakültesi Dergisi, 34, 189-203.

Köstekçi, E. (2016). Öğretmen adaylarının girişimcilik özellikleri ile yansitıcı düşünme düzeyleri arasındaki ilişki. (Yayımlanmamış Yüksek Lisans Tezi). Bartın Üniversitesi Eğitim Bilimleri Enstitüsü. Bartın. 
MEB. (2018). Müzik öğretim programı, Ankara.

Okan, H. (2010). Yansitıcı düşünme etkinliklerinin piyano öğrenme sürecinde öğrencilerin akademik başarısına etkisi. e-Journal of New World Sciences Academy, 5(3), 128-138.

Otacioğlu, S. G. (2008). Müzik psikolojisi I müzik psikolojisinin ABC' si. İstanbul: Öğreti Yayınları.

Phillips, K. ve Stevens, H. (2001). A teacher/Action research study of student reflective thinking in the choral music rehearsal by Harvey Morris Stevens. Bulletin of the Council for Research in Music Education, 150, 97-99.

San, İ. (1977). Sanatsal yaratma, çocukta yaratıcıllk. Ankara: Türkiye İş Bankası Kültür Yayınları.

Saygılı, G. ve Tehneldere, S. (2014). Eğitim çalışmalarının yansıtıcı düşünme becerilerinin çeşitli değişkenler açısından incelenmesi. Mehmet Akif Ersoy Üniversitesi Sosyal Bilimler Enstitüsü Dergisi, 6(11), 192-202.

Sevgi, S. ve Zihar, M. (2020). Ortaokul öğrencilerinin yansıtıcı düşünme becerileri ile matematik öz yeterlik algılarının çeşitli değişkenler açısından incelenmesi. Kastamonu Education Journal, 28(6), 2331-2345.

Semerci, Ç. (2007). Öğretmen ve öğretmen adayları için yansıtıcı düşünme eğilimi ölçeğinin geliştirilmesi. Kuram ve Uygulamada Eğitim Bilimleri, 7(3), 1351-1377.

Sungur, N. (1992). Yaratıcı düşünce. (1. Baskı). İstanbul: Özgür Yayın Dağıtım.

Şahin, Ç. (2004). Problem Çözme Becerisinin Temel Felsefesi. Kazım Karabekir Eğitim Fakültesi Dergisi, 10.

Şahin, A. (2011). Türkçe öğretmeni adaylarının yansıtıcı düşünme eğilimlerinin çeşitli değişkenler açısından değerlendirilmesi. Elektronik Sosyal Bilgiler Dergisi, 10(37), 108119.

Şimşek, O. F. (2007). Yapısal eşitlik modellemesine giriş: temel ilkeler ve lisrel uygulamaları. Ankara: Ekinoks.

Tümkaya, S. ve Hurioğlu, L. (2013). Öğretim elemanlarının yansıtıcı düşünme eğilimleri. Ç.Ü. Sosyal Bilimler Enstitüsü Dergis, 22(1) 243-256.

Tabachnick, B. G. ve Fidell, L. S. (2001). Using multivariate statistics (4th ed.). Needham, MA: Allyn \& Bacon.

Winner, E. (1993). Arts Propel: A handbook for visual arts, Educational Testing Service and the President and Fellows of Harvard College.

Yıldırım, C. (2012). Bilimsel süreç becerileri etkilerinin ilköğretim 7. Sinıf öğrencilerinin yansitıcı düşüncelerine etkisi. (Yayımlanmamış Yüksek Lisans Tezi). Pamukkale Üniversitesi Fen Bilimleri Enstitüsü. Denizli.

Yumuşak, G. K. (2015). Öğretmen adaylarının yansıtıcı düşünme eğilimleri ve mesleğe yönelik tutumları. Bartın Üniversitesi Eğitim Fakültesi Dergisi, 4(2), 466-481.doi: 10.14686/buefad.v4i2.1082000206

\section{EXTENDED ABSTRACT}

\section{Introduction}

The concept "reflective thought" introduced by Dewey to the educational world refers to a comprehensive high-level thinking skill intertwined with critical thinking, problem solving, 
metacognitive thinking and creative thinking. Highlighting the quality of learning-teaching processes in all areas of education, reflective thinking is a skill that teachers are expected to be equipped with as of their studentship. Further, teachers are required to foster their reflective thinking skills. Although reflective thinking skill is important for all trainers, it is even more important for music trainers. This is because the reflection of sensing, perceiving and making sense of music, which is an abstract art branch into the effective use of the sound and instrument, musical literacy and the development of the power of musical expression and musical creativity is a highly set of complex behaviors. Such set of behaviors encompass many critical points to overcome and many problems to be solved. Solving problems and overcoming critical points serve as a basis for the development of students' musical potential. Thus, the mutual interaction between the music teacher and the student becomes out of the ordinary and turns into an art. This transformation not only enriches students' lives through music, but also allow them to explore the world from a different perspective, develop a multi-dimensional thinking skill in solving the problems they encounter in daily life, and adopt an aesthetic lifestyle. The factor that makes this process out of the ordinary is the music teacher's reflective thinking skill. A music teacher with a well-developed reflective thinking skill develops a questioning attitude towards the effectiveness of the his/her own learning-teaching process taking a look at himself/herself from an outside perspective. The teacher being self-critical takes the first step to transform the intended activities regarding the learning areas such as listening-singing, musical perception and information, musical creativity and music culture into an effective learning-teaching process, and seeks ways to improve the activities he/she questions. The music teacher uses his/her accumulated knowledge and skills and creative potential whereby he/she plans and implements the learning-teaching process with the goal to maximize students' musical potentials. The teacher therefore effectively bonds with critical thinking, problem solving, metacognitive thinking and creative thinking skills which are considered as components of reflective thinking. Cultivating the reflective thinking skills among music teachers and preservice music teachers is very significant in terms of the highest quality music education. Increasing the number of limited researches in our country and developing measurement tools will serve as a basis for the development of reflective teachers and students.

The purpose of this research is to develop a valid and reliable reflective thinking tendency scale for music teachers and preservice music teachers. This study is of vital importance since it is the first reflective thinking tendency scale for music teachers and preservice music teachers. In addition to that, there is no validity and reliability study with respect to "reflective thinking skill scale for music teachers and preservice music teachers" in the literature. It is believed that the present study will shed light on not only further studies identifying the reflective thinking skill levels of music teachers and preservice music teachers but also adjustments for cultivating teachers' reflective thinking skills in music teacher training programs.

\section{Method}

The method of the research was the survey model. The study group was determined using the appropriate sampling method. The study group of this research is composed of two independent datasets with sample size of 634 suitable and volunteer participants. The sample size were 362 participants for EFA and 272 participants for CFA.

Participants of the study have the following characteristics:

- Those who graduated from music education departments of education faculties and volunteer to answer the scale.

- Those who graduated from various music schools, attended pedagogical formation training programs and volunteer to answer the scale

- 2nd, 3rd and 4th grade students studying in music education departments of education faculties and volunteering to answer the scale 
the scale.

- Those who are graduate students of the music teaching program and volunteer to answer

The data were collected from two independent datasets. The data were analyzed by exploratory and confirmatory factor analyzes. The adequacy of sampling was tested through Kaiser-Meyer-Olkin test and Bartlett's test of sphericity was utilized for adequacy of correlation between variables. The maximum likelihood estimation was used to determine the parameters of the stack to which the data belongs and direct oblimin method was used to determine the degree of correlation among factors. The Cronbach-Alpha coefficient was used to estimate the internal validity of the factors. A pre-trial form with 45 items was first applied to the group of 362 participants reached in January 2021 whereby it was intended to assess the construct validity of the scale and an exploratory factor analysis was administrated to the data obtained. Following the analysis, a 16-item scale consisting of four factors was applied to 271 participants who were reached in February 2021, and a confirmatory factor analysis was performed on the data obtained.

\section{Results}

Kaiser-Meyer-Olkin test was first used for the sampling adequacy of the exploratory factor analysis to assess the construct validity of the scale. According to the test results, KMO test value was found to be .885 and the degree of freedom (df) was 120 . These results prove that the sample is sufficient $(p<0,00)$. Following the Bartlett's test of sphericity implemented to test the adequacy of correlation among variables, the values were obtained as $\mathrm{x}^{2}=3444,481 ; \mathrm{df}=120(\mathrm{p}<0,01)$. Additionally, it was seen that the scale has four sub-factors with an eigenvalue greater than 1 , and these four sub-factors explained $71,35 \%$ of the total variance. The correlation between scale items was found to be above .20. Consequentially, the direct oblimin method was used since the items are related to each other. As a result of the analysis, the scale consisted of 16 items and four factor. The first factor explained 43,85\%, the second factor accounted for 11,24, the third factor explained $9,4 \%$, and the fourth factor accounted for $7,2 \%$ of the total variance. The cut-off value for factor loadings was determined as .50. The factor load values of the scale vary between .768.878 in the 1st factor, $.738-.823$ in the 2nd factor, .536-.790 in the 3rd factor, and .589-.852 in the 4th factor. Following the analysis of the items related to the factors, the first factor was named as "problem solving in voice education", the second factor was named as "planning and evaluating in creativity", the third factor was named as "reflecting and evaluating the experiences" and the fourth factor was named as "developing a strategy for facilitating learning ". The Cronbach-Alpha internal consistency coefficient for the overall scale was calculated as 0,91 . The Cronbach-Alpha coefficients of the factors were 0,89 for the 1 st factor, 0,886 for the 2 nd factor, 0,824 for the 3rd factor, and 0,863 for the 4 th factor. These values demonstrate that each factor has a high degree of internal validity. The four-factor structure was tested by confirmatory factor analysis. According to the results of the confirmatory factor analysis, the values were obtained as RMSEA= $0,058(90 \%$ confidence interval $=0,044-0,072), \mathrm{CFI}=.96, \mathrm{IFI}=.96, \mathrm{AGFI}=.89, \mathrm{GFI}=.93$, and $\mathrm{RMR}=.030$. Chi-square $=159,23, \mathrm{df}=83$. The fact that the chi-square $/ \mathrm{df}$ is 1,91 following the last modification indicates that the model is in perfect harmony

\section{Discussion and Conclusion}

When the reflective thinking tendency scale for music teachers and music teacher candidates is compared with other reflective thinking scales developed for teachers and teacher candidates (Semerci, 2007; Çiğdem and Kurt, 2012; Başol and Gencel, 2013), the most distinctive difference is that the items and factors of this scale are specific to the field of music. In addition, when the factors in the scales are examined, it is seen that although the names seem to be very different, the factors have common points such as the teachers and pre-service teachers' critical view of themselves and the learning process, problem solving and making arrangements that will make the learning process effective. 
As a result of this research, exploratory factor analysis revealed that factors had high internal validity, and confirmatory factor analysis revealed that the scale was in a perfect harmony.

In light of the results obtained, we could contend that this 5-point Likert type scale consisting of 4 factors and 16 items might serve as a base for future studies in music education by filling the gap in the field. 